\title{
CATEGORIZATION OF SIIFAT MUSYABBAHAH (ATTRIBUTIVE ADJECTIVES OF ARABIC)
}

\section{Mohamad Afrizal*}

Syamsul Hadi dan Suhandano**

* Alumni Program Doktor, FIB Univ. Gadjah Mada dan Dosen Univ. Muhammadiyah Jember

**Fakultas Ilmu Budaya, Universitas Gadjah Mada, Yogyakarta

e-mail: afrizal@unmuhjember.ac.id

\begin{abstract}
ABSTRAK
Sifat musyabbahah (SM) merupakan subkelas nomina Bahasa Arab, yang dimunculkan oleh para tata bahasawan klasik Bahasa Arab, yang bentuk dan maknanya tidak teratur. Tulisan ini bertujuan untuk mengkategorikan SM melalui pendekatan kelas kata lintas-bahasa. Data berupa SM bebas konteks dan SM terikat konteks yang diperoleh dari buku-buku tata bahasa Arab, serta korpus dan kamus daring Bahasa Arab. Kemudian, data dianalisis dengan pendekatan kelas kata lintas-bahasa, yaitu integrasi analisis sintaksis, morfologi, dan leksikal. Hasilnya ialah SM dapat dikategorikan ke dalam 6 jenis SM yang meliputi 1) SM dalam arti sempit, 2) SM sebagai bentuk/wazan antara ism fä'il dan ism maf' ūl, 3) SM sebagai inkorporasi nomina absolut, 4) SM sebagai leksikalisasi metaforis, 5) SM sebagai istilah kekerabatan dan kategori sosial, dan 6) ism non-SM.
\end{abstract}

Kata kunci:

Sifat musyabbahah, gramatika tradisi Arab, pengkategorian, kelas kata lintasbahasa

\section{INTRODUCTION}

Sifat musyabbahah (SM) is one of important subjects in Arabic grammar that have irregular word-form and meaning. In this section, it will be presented what SM is, the problems, and research focus.

\section{Notions of SM and the problems}

Definition of $S M$

$\mathrm{SM}$ is one of Arabic noun subclasses. Generally, SM is defined based on potential to be noun attribute, derivation, and abstraction of lexical features. For example, Al-Yamaniy \& AnNūr (2016:1) who elaborated various definitions of SM from various classical Arabic grammatical literatures ${ }^{1}$ stated that:

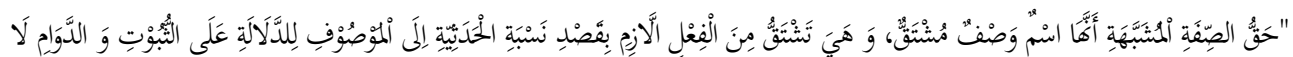

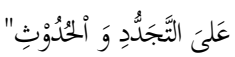

'The essence of sifat musyabbahah is a derivative attributive noun, which is derived from intransitive verb in order to relate an event to an attributed-for

\footnotetext{
${ }^{1}$ written by e.g. Ibn Hisyām, Ibnu Mālik, Sībawaih, Ibn Sirāj, Asymūniy, 'Abbās Ḥasan
} 
noun (maușüf), to indicates a state or habituativeness, nor continuousness or progressiveness.'

The definition of SM may differ from one grammarian to others. The difference is in terms of derivation. Al-Gulāyainiy (1993:185) claimed that SM is not only derived derived from

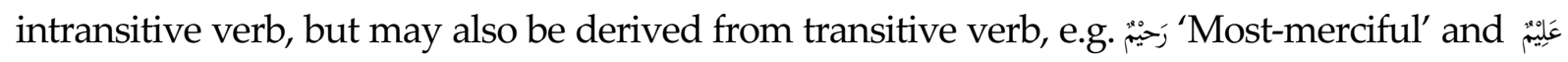
'All-Knowing'. On the other hand, Ad-Dahdāh (1996:84) mentioned that SM is derived from gerund (mașdar), not from verb.

Aziz (2009:17-18) said that the classical Arabic grammarians paid much attention to declinable noun (ism mutașarrif) which has action of declension ('amal) like verb. This noun is distinguished from other types of declinable nouns ${ }^{2}$ which may also have inflective operation like verb. This noun is called sifat. The term sifat may refer to both function and meaning. When referring to functions, șifat is interpreted as nouns that may be employed as attributive functions in attributive noun phrases (tarkib wasfiy). Conversely, when referring to meaning, șifat is interpreted as ism with the meaning of "properties". Furthermore, this type of ism is called sifat al-musyabbahah bi l-fa'il or bi-ism l-fa'il because it is like ism fä'il in term inflective operation, i.e. to nominativize subject (li-raf'il fá'il). In addition, Arabic grammarians more discussed morphological and syntactic characteristics of SM and ignored lexical characteristics.

SM-patterns

SM has various word-patterns (wazn). Al-Gulāyainiy (1993:186-191) mentioned four

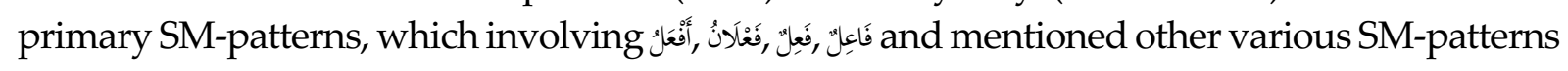
as outcome from morphophonological process. On the other hand, Mustarīhiy (2003) mentioned four types of SM-patterns consisting of a) 18 types $^{3}$ of SM-patterns, b) like active

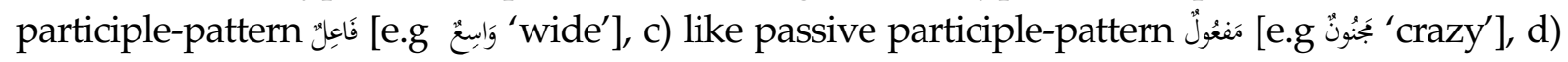
and attached to frozen noun-pattern (ism jāmid) ${ }^{4}$. In addition, Mustarīhiy also mentioned that

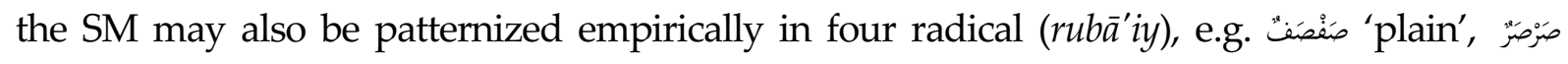
'furious (of wind)', and in other noun-patterns such as absolute noun and gerund intended as sifat. From all SM-patterns which are mentioned already, no exclusive pattern for SM.

Each of SM-patterns overlap with other noun subclasses. Pattern for example, is noun-pattern used for both SM and elative-noun (ism tafdîl). Pattern "ئَ for another example, is not only used for SM, but also for gerund, common noun, excessive noun and broken plural

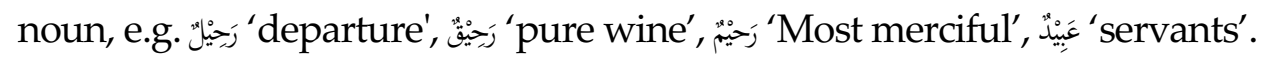

Several SM's have more than single pattern. For examples from Munawwir (1997),

\begin{tabular}{|c|c|c|c|}
\hline & SM & pattern & gloss \\
\hline (1) & 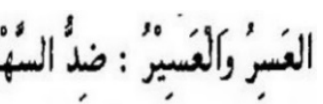 & فَعِلٌ و فَعْيْلٌ" & 'difficult' \\
\hline
\end{tabular}

\footnotetext{
2 i.e. gerund (ism mașdar), active participle (ism fā'il), passive participle (ism maf'ul)

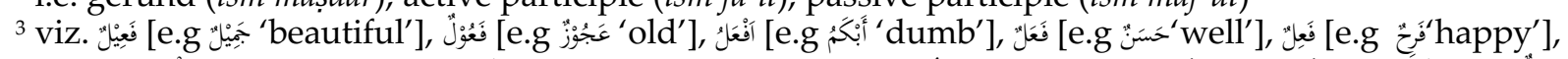

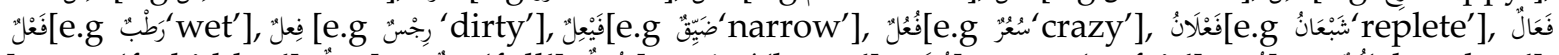

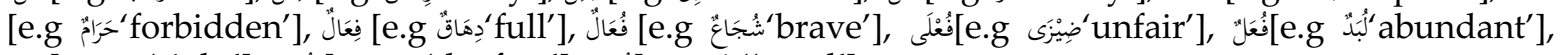

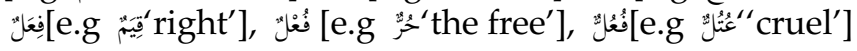

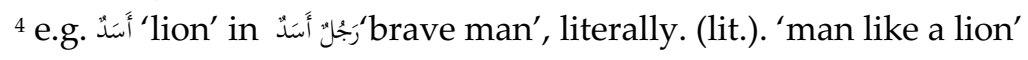


SASDAYA,

Gadjah Mada Journal of Humanities, Vol. 5. No. 1, 2021

\begin{tabular}{|c|c|c|c|}
\hline (2) & 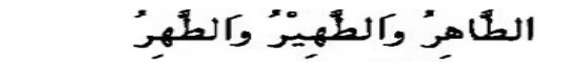 & 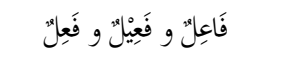 & 'immaculate' \\
\hline (3) & 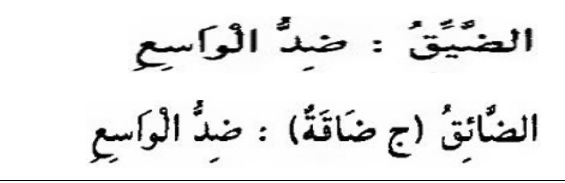 & 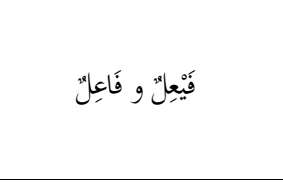 & 'narrow' \\
\hline (4) & 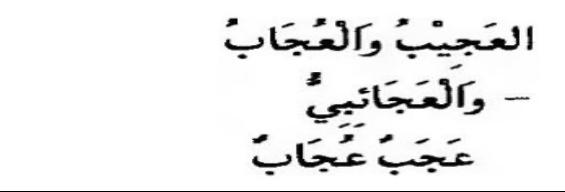 & 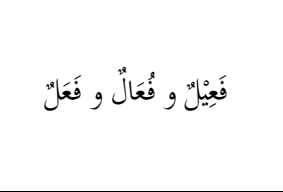 & 'wondrous' \\
\hline (5) & 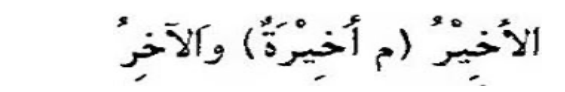 & 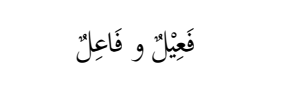 & 'last' \\
\hline (6) & 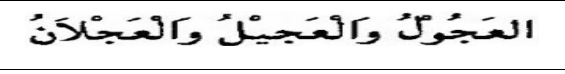 & 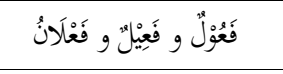 & 'hasty' \\
\hline (7) & 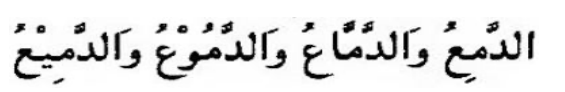 & 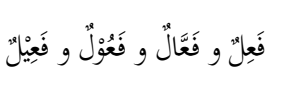 & 'maudlin' \\
\hline
\end{tabular}

The linguistic phenomena in the examples were not much explained by grammarians.

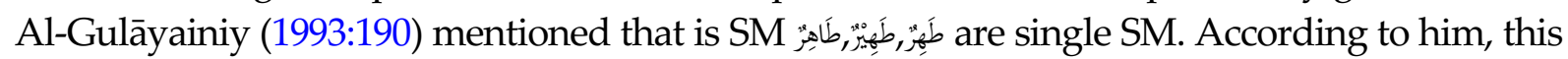
variation is a result of the morphophonological process. This claim may be applied to data 1-3, whereas data 4-6 aren' $t$ very precise. Another possibility is that different patterns allow

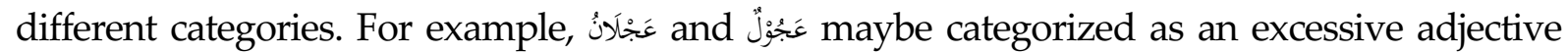

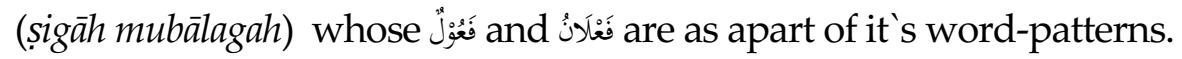

Derivation of SM

As mentioned already, SM is derived from verb. This notion causes three problems. Firstly, it is related to transitivity. Some grammarians believed that SM is only derived from intransitive verbs. However, other grammarians (Al-'Ubaidiy \& Al-Jamīliy, 2012, Al-Mașārawah Invalid source specified., Al-Gulāyainiy, 1993) said that SM can be derived from transitive verbs. The first grammarians group considered what is derived from transitive verbs is not SM, but excessive adjective. Secondly, there are SM's which is asymmetrical to their's verb-pattern. SMtriliteral should be derived from triliteral verb, but there are SM-triliteral derived from augmented-verb (fi'l mazìd) instead. For examples, حَحِيَ 'rocky' is derived from 'to be hard like rock'. Lastly, there are SM`s which verbs don't be found as derivational axis, e.g. لُبْ 'abundant'.

Syntactic Behavior

As mentioned already, SM is one of șifat or ism șifat. This categorization was based on possibility of functioning as șifat (attributive function) in tarkīb wașfiy (attributive noun phrase), e.g,

(1)

fasādun
mischief sing. indef. masc. nominative
<maușū
'great mischief'

kabīrun

great sing. indef. masc. nominative

$<$ șifat>

(2)

$\frac{1}{\text { uswatun }}$

hasanatun 
SASDAYA,

Gadjah Mada Journal of Humanities, Vol. 5. No. 1, 2021

$\begin{array}{ll}\text { example sing. indef. fem. nominative } & \text { excellent sing. indef. fem. nominative } \\ <\text { maușüf> } & <\text { șifat }> \\ \text { 'an excellent example' } & \end{array}$

(3) الصَّفْحَ الجْمِيْلَ

aṣ-ṣafḥa

$\underline{\text { al-jamīla }}$

forgiveness sing. def. masc. nominative

gracious sing. def. masc. nominative

$<$ mausūüs

'gracious forgiveness'

$<$ sifat $>$

Tarkīb wașfiy is a syntactic structure consisting of maușüf (attributed-for) and șifat (attribute). The words fasādun, uswatun, aș-șafha are maușūf, while SM's kabīrun, uswatun, aṣ-șaf̣̣a are șifat. Ad-'Daḥdāh (1996: 338) explained that șifat is a noun modifying maușūf, while maușūf is a noun referring to things, proper nouns, or ideas. Sifat must be agree with maușüf regarding number (singular, dual or plural), gender (masculine or feminine), definiteness (definite or indefinite), dan case (nominative (marfü'), accusative (manșūb), genitive (majrūr)). Al-Gulāyainiy (1993: 97) stated that maușūf decides grammatical category of sifat. There are 15 rules of agreement between mașūf and șifat as mentioned by Dror (2013:56).

Sifat is not only filled by SM, but also can be filled by other noun subclasses, viz. active participles, passive participles, elative nouns, the excessiveness, relative nouns (ism manșūb), as well as gerunds and absolute nouns (ism jāmid) reffering to șifat (properties) (Al-Gulāyainiy, 1993: 97-98). For examples,

(1) <ism fä'il>

رَبجُلْ قَاتِلُْ

rajulun qātilun

man sing. indef. masc. nominative $\quad$ kill (er/ing) sing. indef. masc. nominative

'a killer man' or 'man who killing'

(2) <ism maf' $\bar{u} l>$

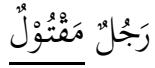

rajulun

maqtulun

man sing. indef. masc. nominative

killed sing. indef. masc. nominative

'a killed man' or 'man who is killed'

(3) <al-mubālagah>

الرَّجُحُ القَتّالْ

ar-rajulu

$\underline{\text { al-qattālu }}$

man sing. def. masc. nominative

murderer sing. def. masc. nominative

'The murderer man'

(4) <ism tafḍil >

السَّجُجُ الْأَعْظَمُ

ar-rajulu

$\underline{a^{\prime} z a m u}$

man sing. def. masc. nominative

great sing. def. masc. nominative

'The greatest man'

(5) <mașdar> 
SASDAYA,

Gadjah Mada Journal of Humanities, Vol. 5. No. 1, 2021

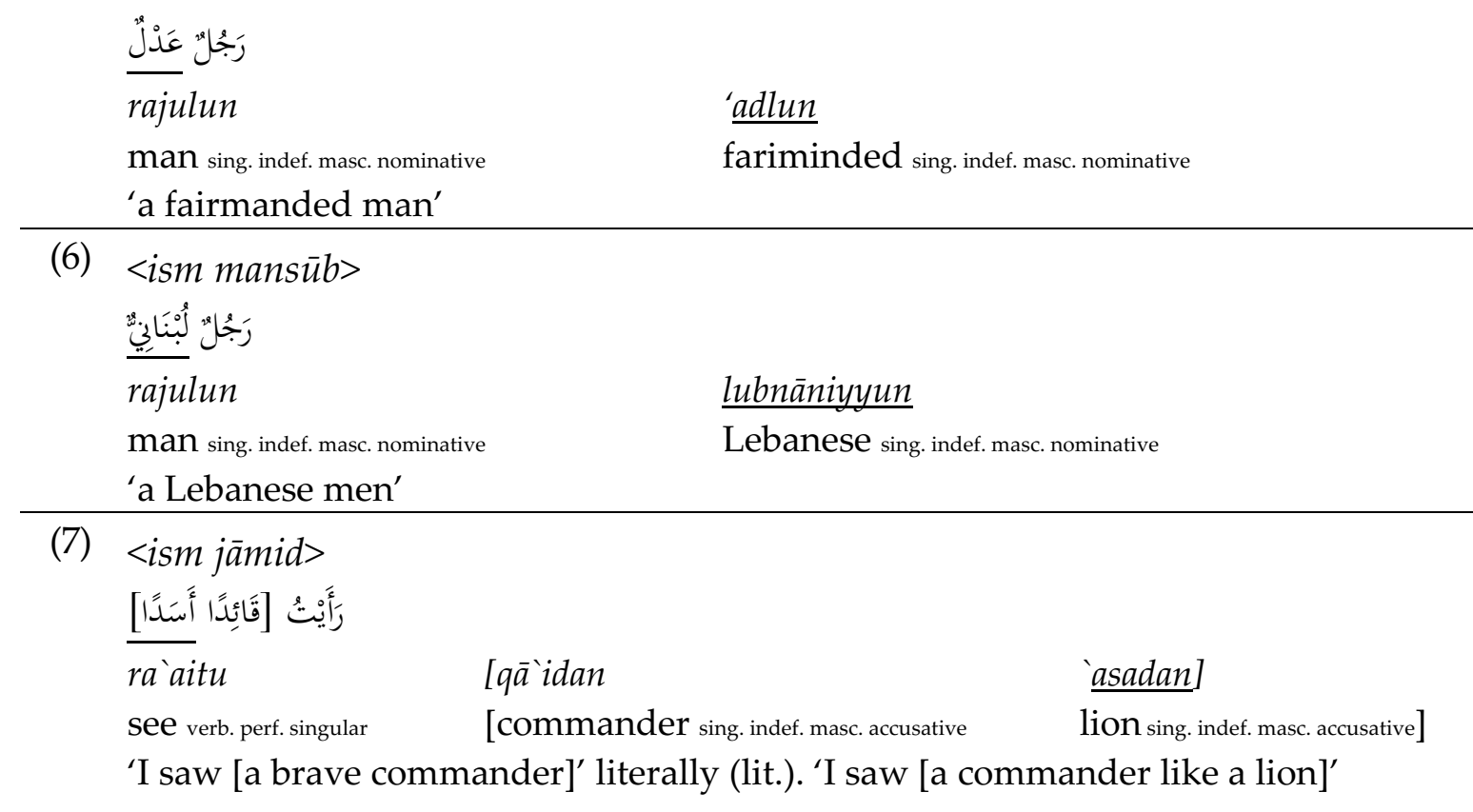

It should be noted that (5) and (7) was listed by Mustarịiy (2003) as SM.

Besides functioning as șifat, SM has 'amal (action of declension) or can be 'ämil (active element of declension). This notion can be found within section talking about 'amal aș-sifat almusyabbahah, viz. sintactic behaviour of SM causing changes of $i^{\prime} r \bar{a} b^{5}$ to word(s) within a clause or phrase. Al-Gulāyainiy (1993: 282-283) mentioned four types of SM action`s of declension, viz.

(1) nominativizes passive element $\left(m a^{\prime} m \bar{u} l\right)$ because of like subject of verbal clause $\left(f \tilde{a}^{\prime} i l\right)$,

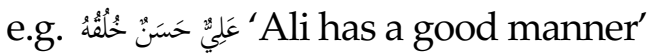

(2) accusativizes passive element because of like object of verbal clause (maf'ūl bih)

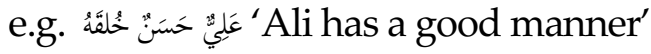

(3) genitivizes passive element because of annexational phrase (tarkīb iḍāfiy),

e.g. 'Ali has a good manner'

(4) accusativizes passive element of specifying contruction (hā $l)$,

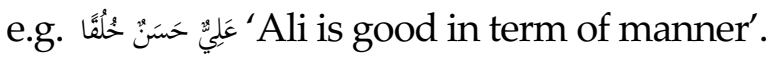

In addition, SM is not the only noun subclass which has 'amal. However, there are others like that, i.e. ism fä'il, ism maf' 'ull, ism tafḍil, mubālagah, and mașdar. Except mașdar, all are șifat.

Lexical features

The lexical meaning of SM is less mentioned. It was claimed that some SM's tendencically have specific lexical features. For example, the pattern 'ُعَ'af'alu is a SM-pattern

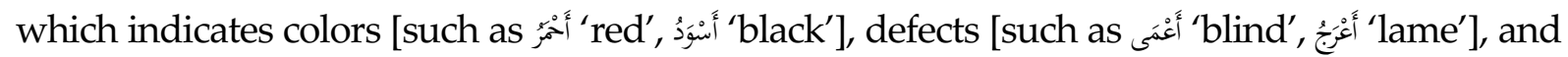

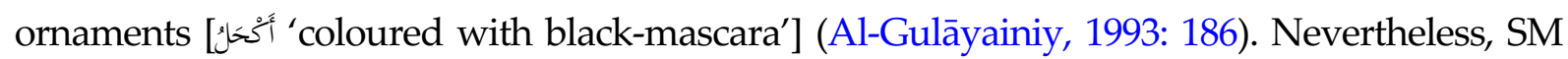

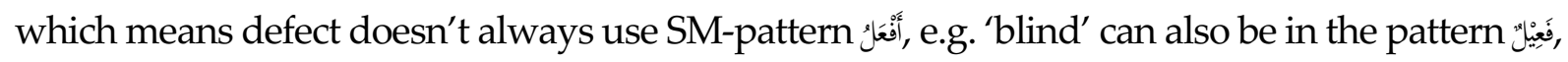

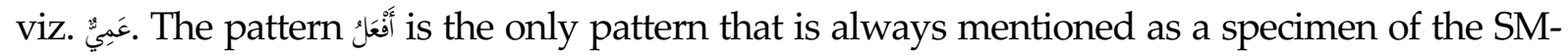
pattern which has regularity of meaning. As for the other SM-patterns, they had never been claimed to have a regularity of meaning.

${ }^{5}$ viz. sets of rules regarding changes to the end of words marking various syntactic cases 


\section{SASDAYA,}

Gadjah Mada Journal of Humanities, Vol. 5. No. 1, 2021

\section{Problem statements and Research focus}

$\mathrm{SM}$ is Arabic noun subclass grammatical rule that was given by traditional Arabic grammarians to accommodate other derivative nouns which may be distributed as sifat, but it cannot be classified as ism fā'il, ism maf'ūl, ism taf̣̣̂l dan șigah mubālagah. This notion causes three problems in the application. Firstly, functioning as șifat is main criteria, so that any ism functioning as șifat must be classified as SM, e.g. the word asadun 'lion' which classified as SM. The second is the problem of derivation (isytiqāq). SM is claimed as a derivative noun, viz. that is derived from verb or infinitive verb/gerund. In the application, it is found that there are SM`s that are asymmetrical against their`s verbpattern, and that there are SM's that they don't have fi'l or mașdar as derivational axis. This shows that SM is derived neither fi'l nor mașdar, but derived from consonant-roots and affixes. This also applies to other Arabic open classes. The third problem is related to SMpattern. SM no has specific word-pattern and has various word-patterns that each overlaps with other noun subclasses. Moreover, several SM's have more than single pattern.

The lexical meaning of SM is less mentioned. Some lexical features of SM that was mentioned by grammarians have not been able to cover all of ism claimed as SM. The lexical features mentioned only indicate to adjectives. In fact, there are SM`s that have lexical features other than adjectives.

As mentioned already, the urgency of this research is that the study of the lexical features of SM was rather ignored. In fact, the study of word classes, or parts of speech, needs to pay attention to the semantic aspects which are then integrated with morphological and syntactic studies (Goddard and Wierzbicka, 2014:1). Therefore, the objective in this study is to analyze SM based on the parts of speech approach, viz. the integration between syntactic and morphological analysis, and lexical feature analysis. The purpose of this analysis is to categorize SM which has various lexical features.

\section{PARTS OF SPEECH}

$\mathrm{SM}$ is one of Arabic word subclasses. Word classes or parts of speech, such as verbs, nouns, and adjectives, are categorizations of words that have similarities of grammatical behavior (Kridalaksana, 2008). Parts of speech is universal property of human languages that can be identified to all human languages, although the principles of categorizations and results are different.

Cross-linguistically, parts of speech can be identified on two principles, viz. similarity of syntactic function and lexical meaning (Dixon \& Aikhenvald, 2004). Syntactically, noun and verb classes are obligatory for all languages. This is because both fill the functions in the three types of basic universal clause as follows.

\section{Basic clause types (Dixon \& Aikhenvald, 2004: 6)}

\begin{tabular}{lll}
\hline Clause type & Nucleus & Core arguments \\
\hline Transitive clause & Transitive predicate & $\begin{array}{l}\text { Transitive subject (A) and transitive object } \\
(\mathrm{O})\end{array}$ \\
\hline Inransitive clause & Intransitive predicate & Intransitive subject (S) \\
\hline Copula clause & Copula predicate (copula verb) & $\begin{array}{l}\text { Copula subject (CS) and copula verb) } \\
\text { complement (CC) }\end{array}$ \\
\hline
\end{tabular}




\section{SASDAYA,}

Gadjah Mada Journal of Humanities, Vol. 5. No. 1, 2021

Each clause consists of one predicate and core arguments, viz. subject, object and complement. The term predicate was originally used in Greek to identify all functions other than the subject. In modern linguistics, the term predicate refers to verbs, both transitive and intransitive verbs, and nonverbals which are considered as verbs. For example, (is) big is a nonverbal predicate in the English clause, the house is big. The core argument is a slot that must present in a clause construction. The subject argument is a core argument that must be presented in all clause types. The object argument only presents in a transitive clause and the copulative complement argument only present in copulative clauses. The subject and object can be identified as noun or noun phrase (NP). Whereas copulative complement can be identified as nouns and sometimes identified as parts of a verbal phrase (copulative verb $+\mathrm{NP}$ ). Analysis of word classes through clauses only focuses on nouns and verbs. This makes both classes as obligatory categories in all languages.

The identification of word classes also needs to involve lexical semantic identification. Dixon \& Aikhenvald (2004: 3-5) suggested three types of semantic words, i.e nouns, verbs and adjectives.

"Semantic types with concrete reference are always linked to the noun class-these include HUMANS (e.g. 'boy'), body and othe PARTS (e.g. 'eye', 'leg'), FLORA (e.g. 'tree', 'leaf'), FAUNA (e.g. 'rat', 'fly') CELESTIAL (e.g. 'sun'), ENVIRONMENTT (e.g. 'water', 'forest'), and ARTEFACTS (e.g. 'gun', 'house')."

"Semantic types always associated with the verb class include MOTION (e.g. 'run', 'take', 'throw'), REST (e.g. 'sit', 'put', 'hold'), AFFECT (e.g. 'hit', 'burn', 'build'), GIVING (e.g. 'give', 'trade'), ATTENTION (e.g. 'see', 'hear'), and SPEAKING (e.g. 'tell, 'shout', 'ask')"

$\cdots$

... "semantic types typically associated with the word class adjective;

1 DIMENENSION-'big', 'small', 'long', 'tall', 'short', 'wide', 'deep', etc.

2 AGE-'new', 'young', 'old', etc.

3 VALUE-'good', 'bad', 'lovely', 'atrocious', 'perfect', 'proper(/real)', etc. (And also words such as 'odd', 'strange', 'curious', 'necessary', 'crucial', 'important', 'lucky').

4 COLOUR-'black', 'white', 'red 'etc.

5 PHYSICAL PROPERTY-'hard', 'soft', 'heavy', 'wet', 'rough', 'strong', 'clean', 'hot', 'sour', etc. And subclass reffering to corporeal properties, e.g. 'well', 'sick', 'tired', 'dead', 'absent'.

6 HUMAN PROPENSITY- 'jeleous', 'happy', 'kind', 'clever', 'generous', 'cruel', 'proud', 'ashamed', 'eager', etc.

7 SPEED- 'fast', 'quick', 'slow', etc.

8 DIFFICULTY-'easy', 'difficult', 'though', 'hard', 'simple', etc.

9 SIMILARITY-'like', 'unlike', 'similar', 'different(/strange)', 'other', etc.

10 QUALIFICATION-'definite', 'true', 'probable', 'possible', 'likely', 'usual', 'normal', 'common', 'correct', 'appropiate', 'sensible', etc.

11 QUANTIFICATION-'all(/whole)', 'many', 'some', 'few', 'only', 'enough', etc.

12 POSITION-'high', 'low', 'near', 'far/distant', 'right', 'left(/strange)', 'northen', etc.

13 CARDINAL NUMBER. (In some language these constitute a separate word class) And 'first', 'last' (together with other ordinal numbers)."

On modern/western linguistics perspective, SM was usually compared with adjectives (Abu-Chacra, 2007; Badawi et al., 2004; Haywood \& Nahmad, 1962; Wright, 1981). Unfortunately, the comparation did not considered tertium comparationis because it did not take into account the differences in structural typology between Arabic and European languages. 


\section{SASDAYA,}

Gadjah Mada Journal of Humanities, Vol. 5. No. 1, 2021

SM was compared with adjectives because SM must be functioning as an attribute/sifah and most of the lexical features of SM are adjectives.

Adjectives are part of the main classes together with verbs and nouns. Not all languages, as well as Arabic, have an adjective class independently. The grammatical characteristics of adjectives can be similar to nouns, or be similar to verbs, or similar to nouns and verbs, or not similar to verbs and nouns (Beck, 2002).

Nevertheless, Dixon \& Aikhenvald (2004) said that adjectives can be cross-linguistically identified by the following criteria.

1. Adjectives can be functioning as attribute in noun phrases.

2. When functioning as intransitive predicate, adjectives can be intransitive verbs or noun complements of copulative verbs.

3. In several languages, adjectives can be identified in comparative constructions.

4. In several languages, adjective can be functioning as adverbs, or modifying verbs, which sometimes may be accompanied by morphological process.

Dixon \& Aikhenvald (2004) also claimed that "the recognition of word classes in a language must be on the basis of internal grammatical criteria for that language".

\section{METHOD}

This study aims to categorize SM based on the parts of speech approach. Hence, the data of this study are context-free SM and context-bound SM (phrase or clause) which were sourced from Arabic grammar books written by e.g. Al-Gulāyainiy (1993), Ad-Daḥdāḥ (1996), As-Sāqiy (1977), Hassān (1985), Naḥlah (1994), and the specific works about SM written by e.g. 'Azīz (2009) Mustarīhiy (2003) and Al-Yamaniy \& An-Nūr (2016). Data used in that works were limited, viz. mostly they was sourced from Al-Qur'ān because it was the main corpus of Arabic grammar (Haywood \& Nahmad, 1962). Therefore, the data were expanded by way of predicting a SM-pattern with a specific root and then searching it into Arabic online corpus and dictionaries'. For example, it was found that the root ضرب ضريب drb 'to hit/beat' has SMn 'to be beaten' after it predicted and searched various possible SM-patterns against root $d r b$, such as darībun, *darbānu, * darabun, dan *daribun.

Data analysis in this study included syntactic, lexical, and morphological analysis. The first is syntactic analysis. Each noun which claimed as SM must be functioning as sifat in tarkīb wasfiy. As for the principle of 'amal, it doesn't need to be applied because nouns which have 'amal include ism mașdar, while it is not be included within ism șifat.

The second is meaning principle. The meaning what is meant is not stativeness ( $\dot{s} \bar{a} b i t a h)$ because this concept is abstract. What is meant by meaning is the lexical meaning which covers lexical meaning of adjectives, nouns, and verbs.

The third is morphological analysis, viz. SM-pattern, verb-pattern of SM, and tafdîl possibility. The analysis of SM-patterns is observing presence or absence of word-pattern

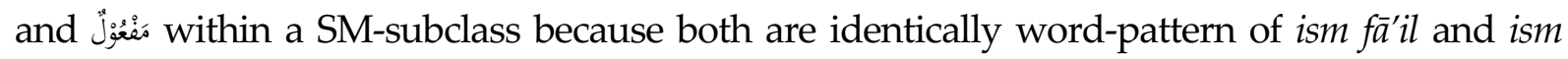
maf' $\bar{u} l$. The derivation analysis of SM is identifying verb-pattern as an axis of derivation, i.e triliteral or others, as well as the transitivity of it`s verb. the potential of SM has a paradigmatic

\footnotetext{
${ }^{6}$ see. the end of article "data source"
} 


\section{SASDAYA,}

Gadjah Mada Journal of Humanities, Vol. 5. No. 1, 2021

relation with ism tafdill, viz. it is noun subclass which has word-pattern and feminine-form, indicating the superlative or comparative. This principle is adopted as was suggested by Dixon \& Aikhenvald (2004: 11) as mentioned above.

\section{RESULT OF CATEGORIZATION}

The research resulted 6 types of SM as follows.

\section{Type 1: SM in narrow sense}

The use of this label followed "adjectives in the narrow sense" given by Dixon \& Aikhenvald (2004: 1). The characteristics of type 1 are which a) must be functioning as sifat, b) has lexical features of adjective, c) is derived from intransitive verb and

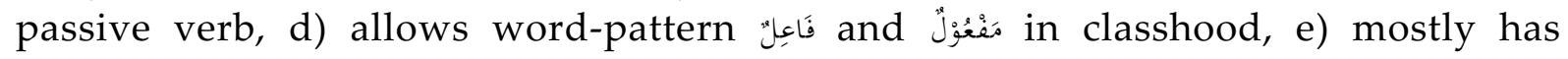
paradigmatic relation with ism tafdîl. Each of characteristics, except a) ${ }^{7}$, are explained as follows.

The type 1 is SM's which theirs classhood has adjective lexical features ${ }^{8}$, viz.

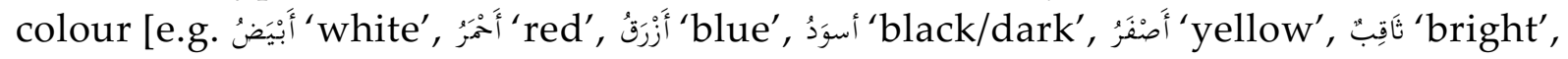

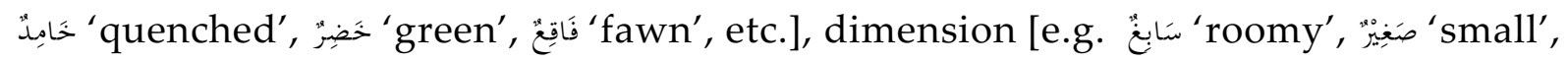

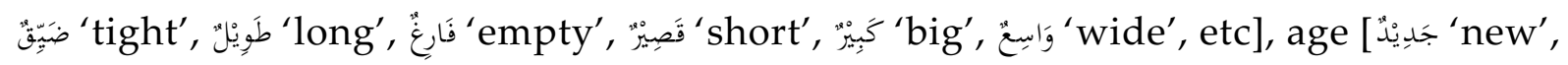

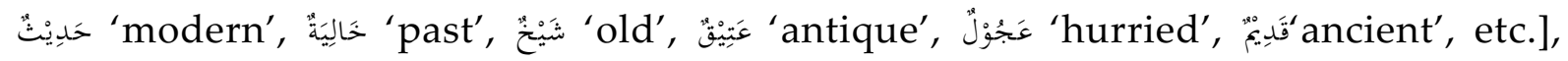

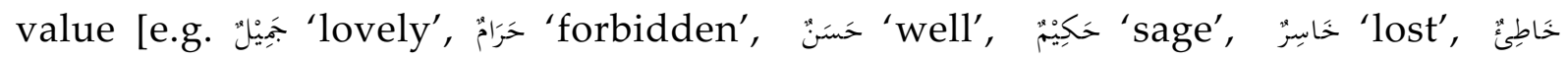

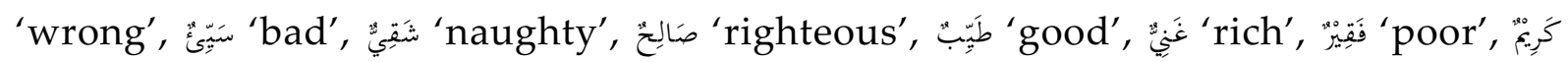
'honourable', etc], speed [e.g. 'slow', 'بَيْيْء 'fast', etc.], physical property [e.g. (for

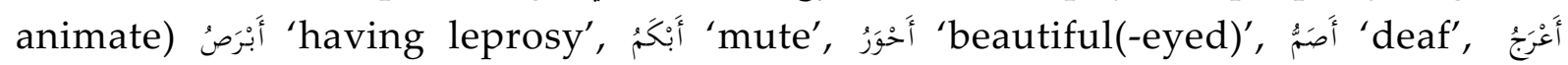

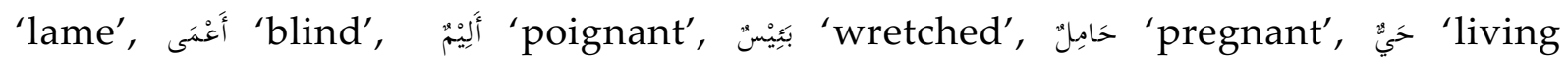

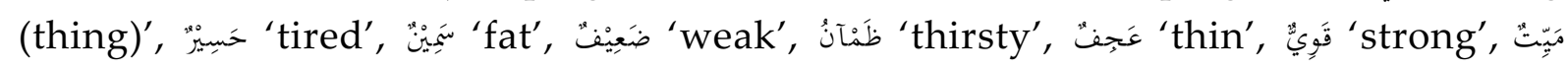

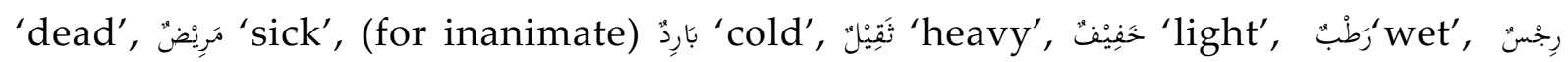

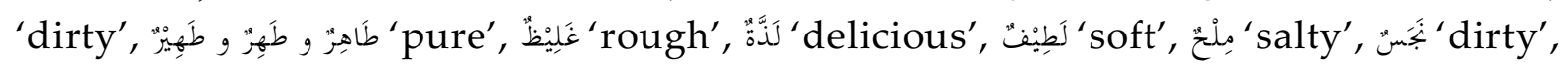

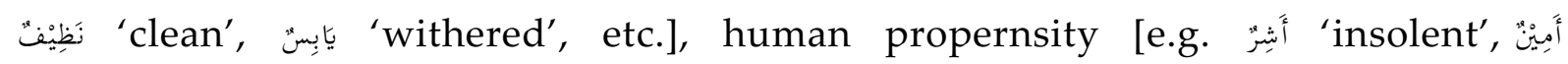

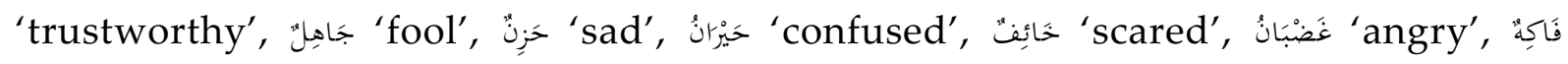

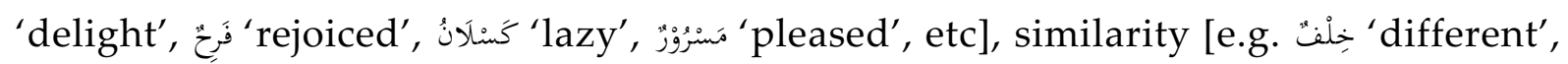

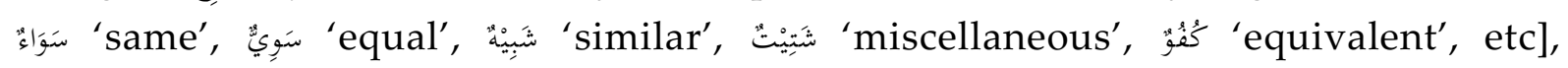

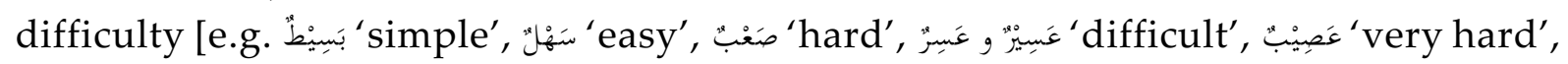

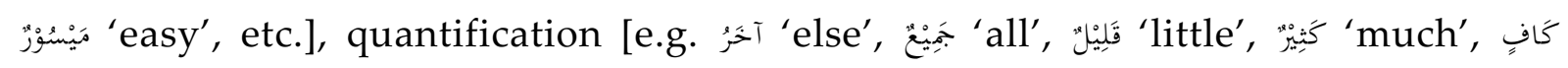

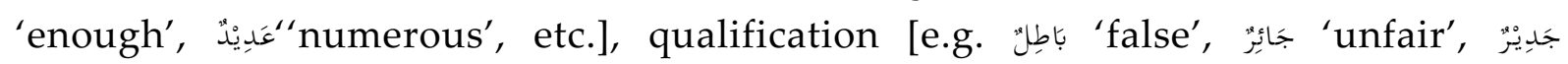

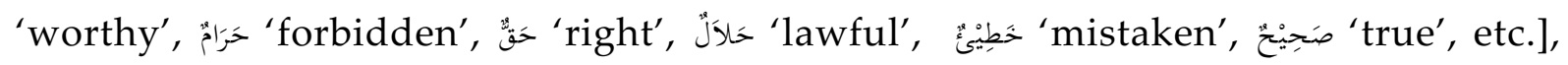

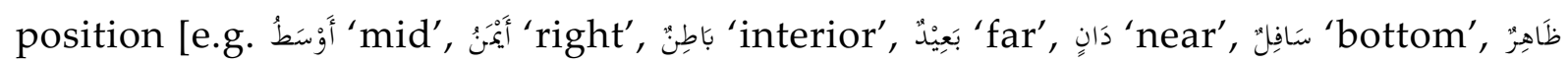

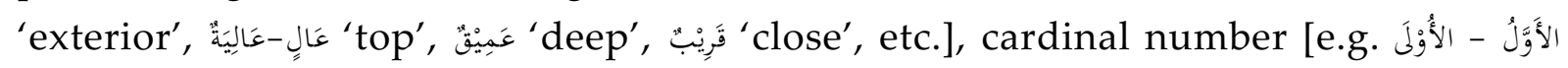
'first', آخخرٌ و أَخِيْر 'llast', etc.].

\footnotetext{
7 cf. Syntactic Behavior for explanations and examples

${ }^{8}$ cf. Dixon \& Aikhenvald (2004: 3-5)
} 


\section{SASDAYA,}

Gadjah Mada Journal of Humanities, Vol. 5. No. 1, 2021

This type is not allowed to be derived from transitive verb. However, it is

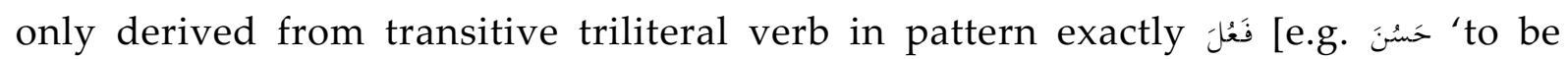

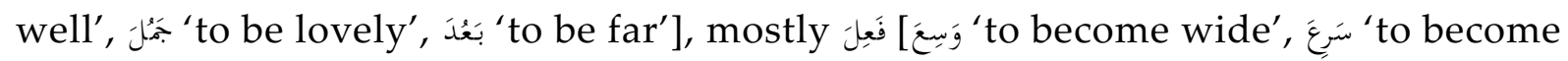

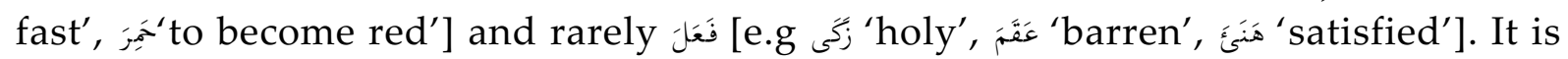

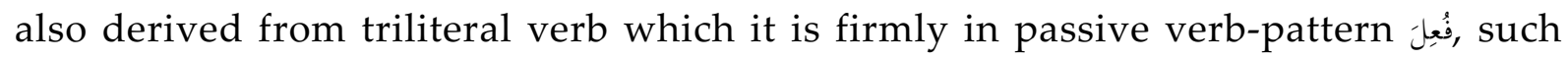

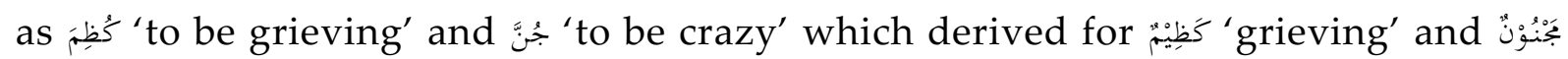
'crazy'.

In this classhood, type 1 is allowed SM-pattern فَاعِلِ

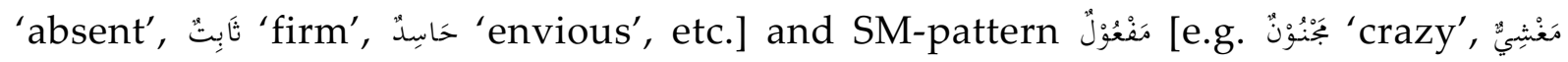

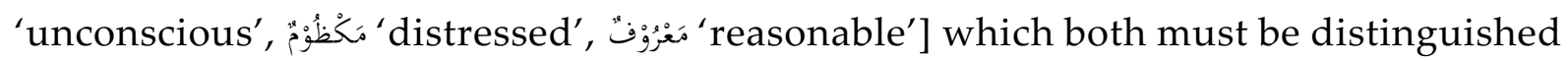

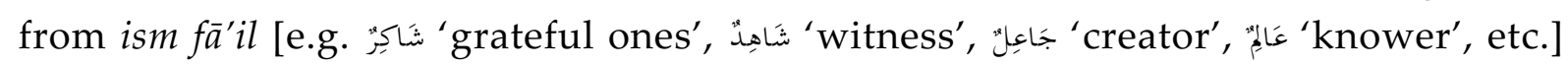

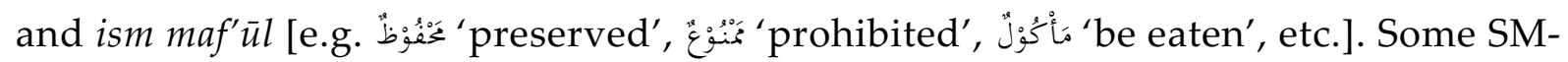

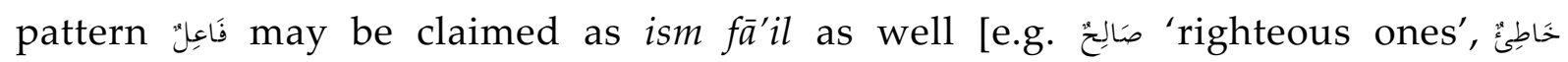

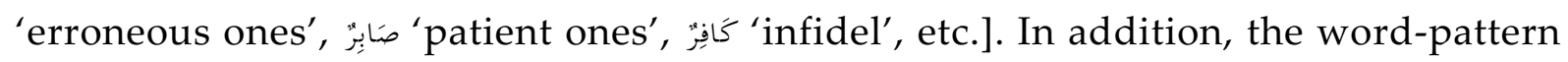
فَاعِلِ doesn't only indicate SM and ism fā'il, but also ism 'adad tartīby (cardinal number) for two to ten and ism mansūb (relative noun) without ya 'nisbah [e.g. لآبنِ 'milked'] (Ad-Daḥdāḥ, 1996: 473).

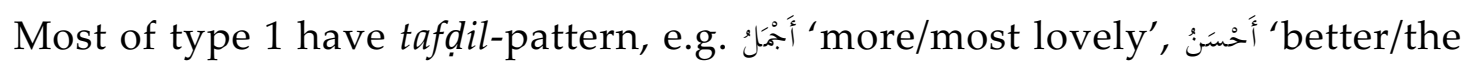

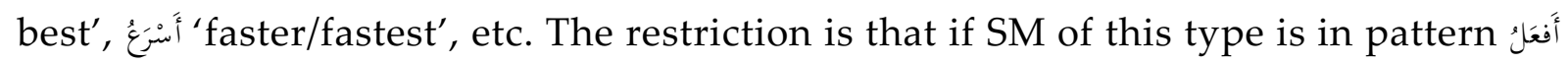

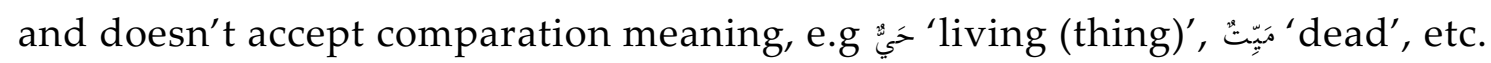

Type 2: SM as alternative word-pattern between ism fä'il and ism maf' $\bar{u} l$

The characteristics of type 2 are which a) must be functioning sifat, b) has lexical features of verbs, c) is generally derived from transitive verb, d) is not allowed

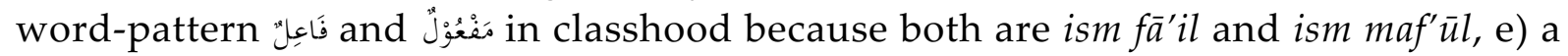
little has paradigmatic relation with ism tafḍil. Each of characteristics, except d) ${ }^{9}$, are explained as follows.

The type 2 must be functioning as sifat. The underlined elements below, for examples, are type 2 of SM functioning as șifat which is as part of tarkìb wașfiy in the brackets.

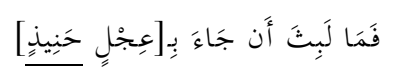

and hastened to entertain them with [a roasted calf]

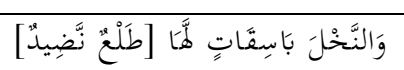

And lofty palm trees having [fruit arranged] in layers

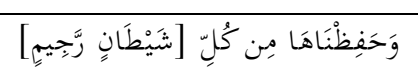

And (moreover) We have guarded them from every [cursed devil]

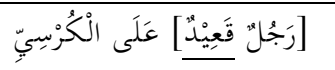

[A man sitting] on the chair

\footnotetext{
${ }^{9}$ see Type 1: SM in narrow sense, paragraph “In class hood, type 1 is allowed SM-pattern ..." for examples and explanations
} 


\section{SASDAYA,}

Gadjah Mada Journal of Humanities, Vol. 5. No. 1, 2021

The type 2 is SM's which theirs classhood has verb lexical features ${ }^{10}$, viz.

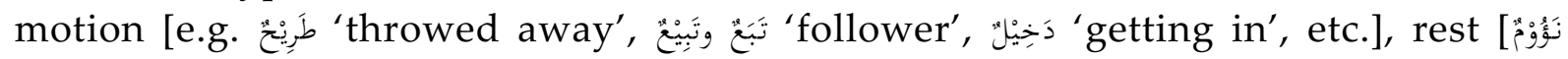

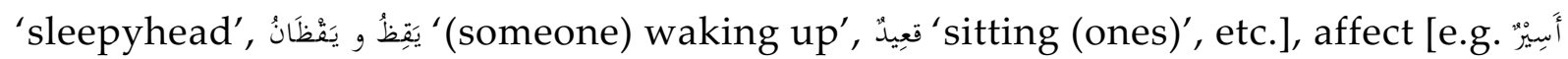

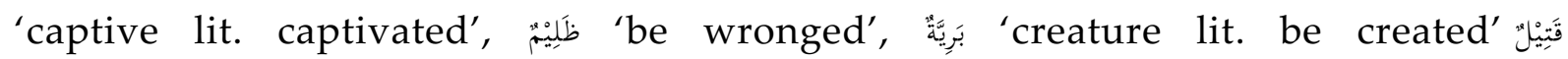

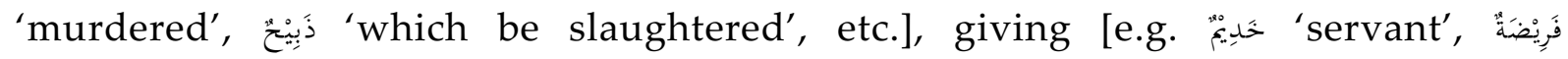

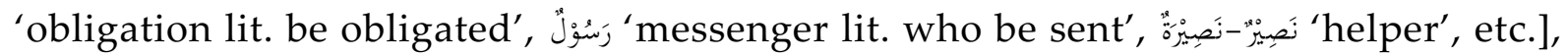

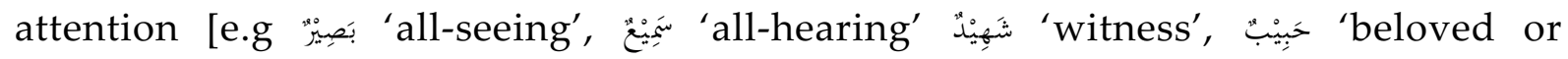

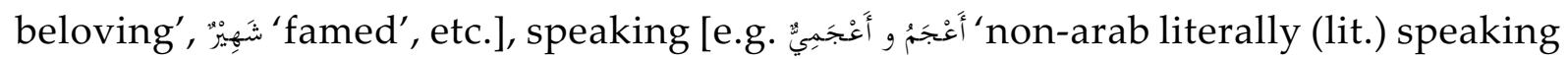

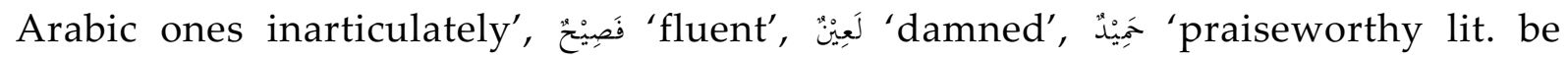
praised', نَبِيُّ و نَبْيٌْ 'prophet lit. messenger', etc.].

This type is only allowed to be derived from transitive verb, viz. which has in

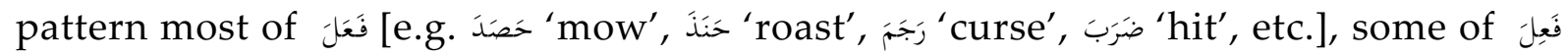

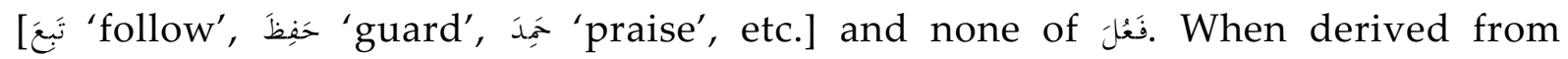
transitive verb, SM indicates either passive meaning or active. If it is active, SM is often accompanied by meaning of excessiveness (mubālagah).

A few of type 2 has tafdìl-pattern. Especially, they are which have lexical features of attention or indicate degree of continuum, e.g. أَحَبُّ 'most/more

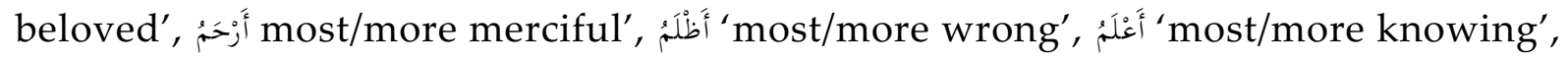
أَفْصَحُ 'most/more eloquent', etc.

\section{Type 3: SM as absolute noun incorporation}

The characteristics of type 3 are which a) must be functioning as sifat, b) has lexical features of nouns, c) is derived from denominal verbs and sometimes has no verbs as derivational axises, $d$ ) isnn't predictable in SM-patterns, e) has no paradigmatic relation with ism tafdìl. The following examples illustrates how SM type 3 is derived.

\begin{tabular}{|c|c|c|}
\hline Absolute noun & SM & Verb \\
\hline \multicolumn{3}{|c|}{ a) body and other parts of human } \\
\hline 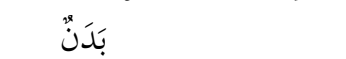 & 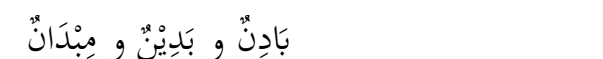 & بَبَدنَ \\
\hline 'body' & 'obese lit. having a big body' & 'to be obese' \\
\hline بَبَطْنُ & بَبطِنُ & بَطُنَ \\
\hline ‘belly' & 'distended' & 'to be distended' \\
\hline بَطُطنْ & مَبْطُطوْنٌ & -- \\
\hline 'belly' & 'stomach pain, heartburn' & \\
\hline ثُذْيْيُو و ثُثَى & ثُثْديَاءُ & --- \\
\hline 'breasts' & $\begin{array}{l}\text { '(of a woman) having large breast, } \\
\text { busty, plump' }\end{array}$ & \\
\hline جَسَسَدُ & جَسَدُ & بَحَْسَسَدَد \\
\hline 'body' & 'bodied' & 'to be bodied' \\
\hline دِ دمَاغُ & دَمِنيغ & دَّمغن \\
\hline 'brain, cerebrum' & 'braining' & 'to be braining' \\
\hline دَدْعُ & دَمِعُع و دَمِيْعِ & دَمِعَ \\
\hline 'tear' & 'maudlin, tearfully sentimental' & '(of tears) to drip' \\
\hline
\end{tabular}

10 cf. Dixon \& Aikhenvald (2004: 3-5) 
SASDAYA,

Gadjah Mada Journal of Humanities, Vol. 5. No. 1, 2021

\begin{tabular}{|c|c|c|}
\hline ر' رَأسيْ & 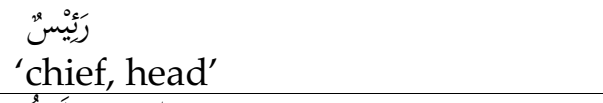 & $\begin{array}{l}\text { 'رَأسنَ } \\
\text { 'to head' }\end{array}$ \\
\hline 'foot or leg' & 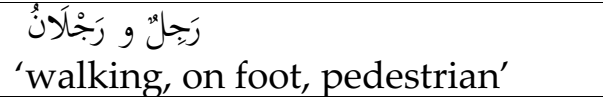 & 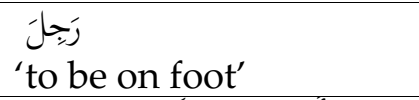 \\
\hline 'hair' & 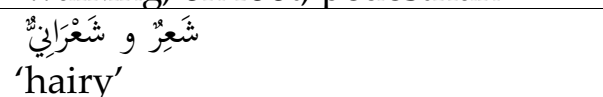 & 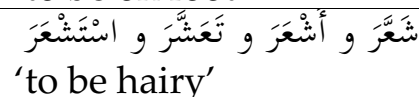 \\
\hline 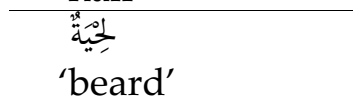 & 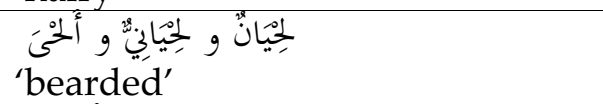 & $\begin{array}{l}\text { التَتَحَى 'to be bearded' } \\
\text { 'to bed }\end{array}$ \\
\hline $\begin{array}{l}\text { شَيْبْ 'gray hair' } \\
\text { 'gray }\end{array}$ & 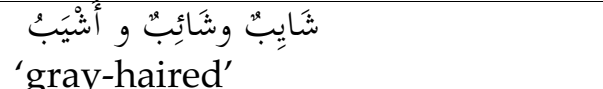 & 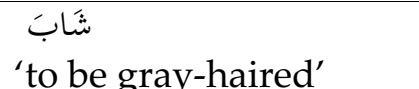 \\
\hline 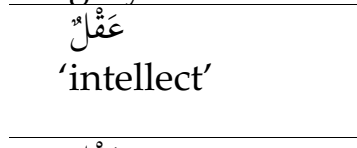 & 'intelligent' & 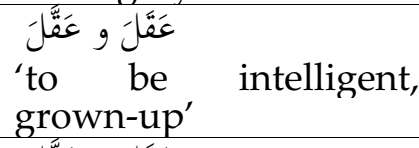 \\
\hline 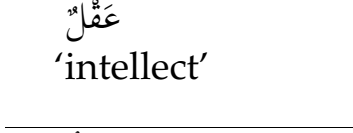 & 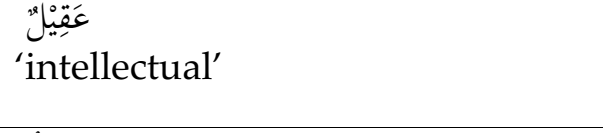 & 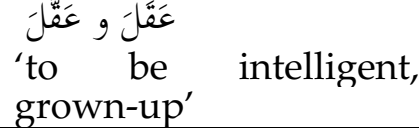 \\
\hline 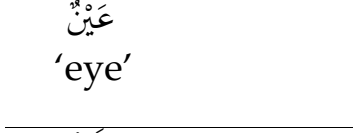 & $\begin{array}{l}\text { 'big and lustrous eyes' } \\
\text { 'big }\end{array}$ & $\begin{array}{l}\text { 'to be big and lustrous } \\
\text { 'eyes' }\end{array}$ \\
\hline 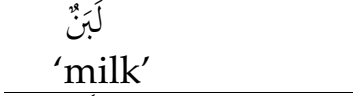 & 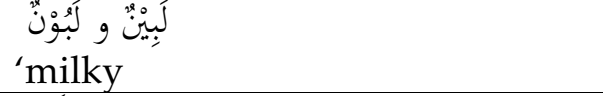 & $\begin{array}{l}\text { 'to breast-feed' } \\
\text { 'toَ }\end{array}$ \\
\hline 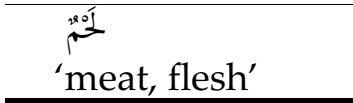 & 'meaty, fleshy' & 'to be meaty, fleshy' \\
\hline b) artefacts & & \\
\hline 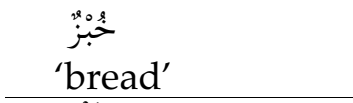 & 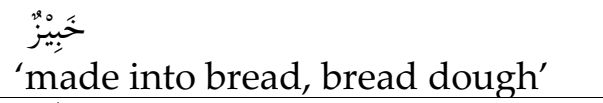 & $\begin{array}{l}\text { خَبَزَ و اخْتَبَزَ 'to make a bread' } \\
\text { 'to }\end{array}$ \\
\hline 'wine' & $\begin{array}{l}\text { 'intoxicated with wine, drunken' } \\
\text { 'iñ }\end{array}$ & --- \\
\hline 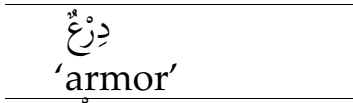 & 'armored' & 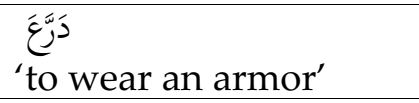 \\
\hline 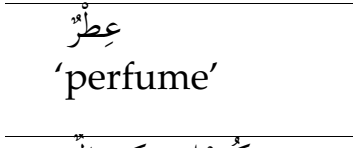 & 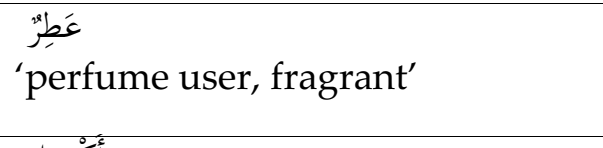 & $\begin{array}{l}\text { عَرِّر be fragrant, use } \\
\text { 'to be } \\
\text { perfume' }\end{array}$ \\
\hline 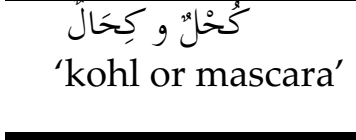 & $\begin{array}{l}\text { 'أكْحَلُ } \\
\text { 'coloured with black-mascara' }\end{array}$ & 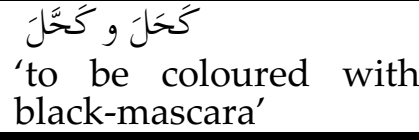 \\
\hline c) environment & & \\
\hline 'stone, rock' & حَحِيْرِ و حَحِرُ 'rocky' & -- \\
\hline 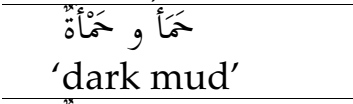 & 'black muddy' & 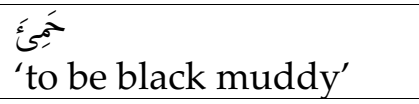 \\
\hline شَُجَرُ و شَجَرَهُ & $\begin{array}{l}\text { شَحِرٌ و أَشْجَرُر } \\
\text { 'woody, (of an area of land) } \\
\text { covered with trees' }\end{array}$ & - - \\
\hline d) celestial & & \\
\hline 'sun' & 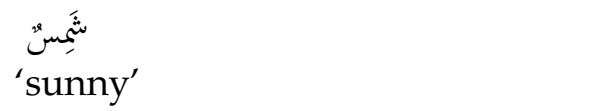 & --- \\
\hline
\end{tabular}

Generally, the SM-pattern of type 3 may be different with its noun-pattern. Whereas, which has SM-pattern similarly with its noun-pattern is jasadun as mentioned in the examples. SM-patterns of classhood cannot predictable. In classhood, type 3 is allowed SM-pattern 
SASDAYA,

Gadjah Mada Journal of Humanities, Vol. 5. No. 1, 2021

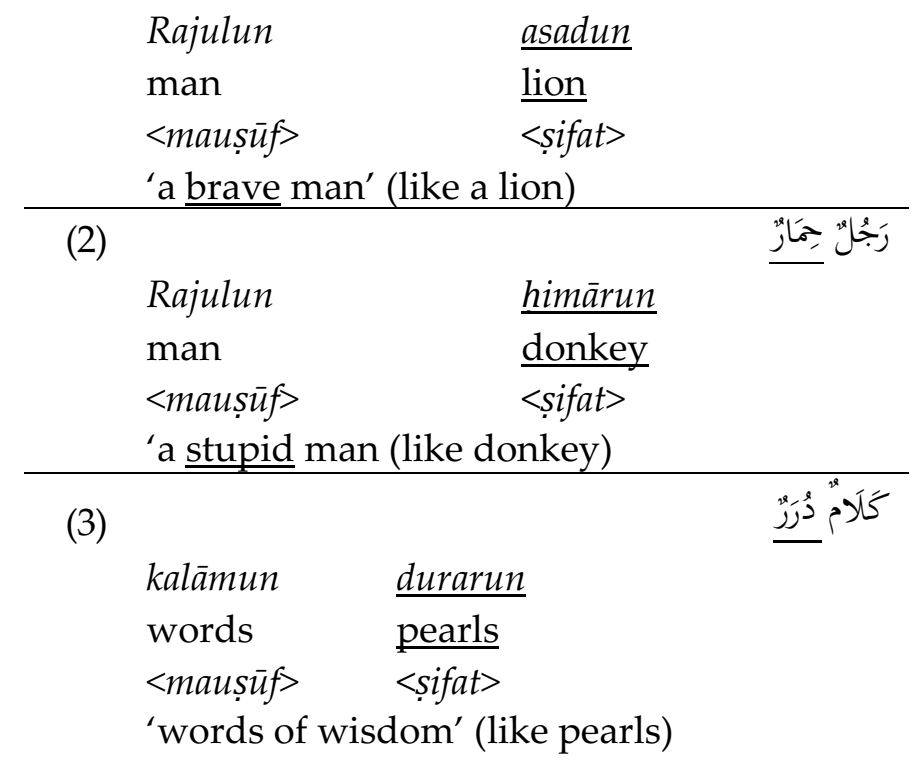

The underlined elements above are absolute noun having lexical content fauna and artefact. They are functioning as sifat which aims to explain similarity of charateristic or behaviour between șifat and maușuf. In Arabic tradition, these phrases construction are encoded as "tasybīh".

Etymologically تَّبَ tasybīh is to similarize. Tasybìh, according to Al-Jārim \& Amīn, (1999: 20 ), is to explain one thing or some things with another one because of one similar characteristic or more. Tasybih can be counterparted with term "metaphor" in western linguistics tradition. Metaphor is defined by Lakoff \& Johnson (2003) as "understanding and experiencing one kind of thing in terms of another". According to Bauer (2000), metaphor is one way of making new words by giving a new meaning to an old word. The metaphor commonly used in human language make it possible to create new lexeme and this phenomenon was named lexcilazation of metaphor (Bauer, 2000: 833). So, the word asadun, for Arabs, is reused to symbolize braveness", himārun to "stupidity", and durarun to "valuableness". These examples at least prove this lexicalization. It also may be investigated through presence of denominal verb within Arabic dictionaries. For examples, we can find denominal verb asida and zaiba within ArabicIndonesian dictionary Al-Munawwir (1997, 23 and 436) as below this paragraph. However, not all metaphorical SM's have a verb-form.

\section{(In English)}

- to become confused because seeing a lion

- $\quad$ to become (or be similar with) a lion (in character)

- lion

- $\quad$ the brave, the intrepid

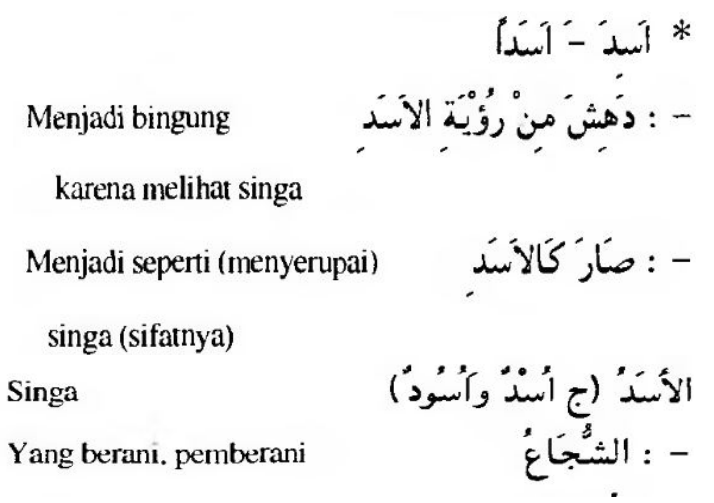


SASDAYA,

Gadjah Mada Journal of Humanities, Vol. 5. No. 1, 2021

- to resembling a coyote (in cunningness and evilness)

- a coyote, wolf

- thieves, weak people, poor and insulted

Menyerupai anjing hutan

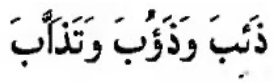
(licik dan jahatnya)

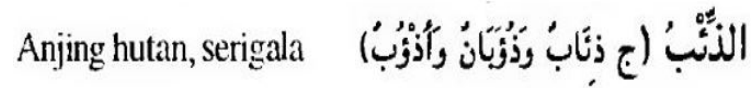

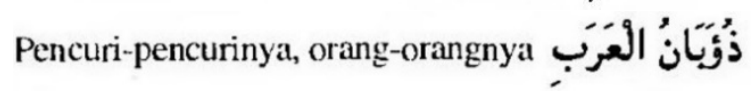
yang lemah, miskin dan hina dina

\section{Type 5: SM as term of kinship and social category}

The characteristics of type 5 are which a) a few may be functioning as sifat, b) has lexical features of kinship term and social category, c) is derived from denominal verbs and is often not found the verbs as the derivational axis, d) is in same pattern with its noun-pattern, e) has no paradigmatic relation with ism tafdîl.

The following table provides examples of SM type 5 and available feminine forms, and the verbs as derivational axises.

\begin{tabular}{|c|c|c|c|}
\hline SM & & Verb & \\
\hline أنتَى & 'Woman' & --- & \\
\hline 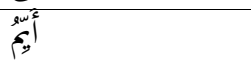 & 'single, unmarried, sole' & آمَ & 'to be sole' \\
\hline ثُثِيَّبْ & 'widow/widowed' & ثُثِيّبَ & 'to be widowed' \\
\hline 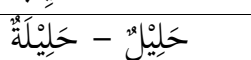 & 'husband-wife' & أَحَلَّ & 'to become lawfull' \\
\hline خِدْنُ & $\begin{array}{l}\text { 'mistress, concubine, secret } \\
\text { lover' }\end{array}$ & خَادَنَ & 'to get a concubine' \\
\hline خَلِيْلِ - خَلِيْلِة & 'friend' & خَالَ & 'to be friend with' \\
\hline دَعِبهُ & 'adopted son' & أَدْعَى & $\begin{array}{l}\text { 'to confess as adopted } \\
\text { son' }\end{array}$ \\
\hline ذَكَرُ & 'man' & --- & \\
\hline زَوْجُج - زَوْجَةٌ & 'husband-wife' & تَزَوَّجَ & 'to marry' \\
\hline سَلَفْ & 'ancestor, predecessor' & سَلَفَ & 'to predate' \\
\hline 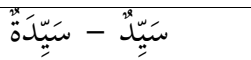 & 'Mr. - Mrs.' & 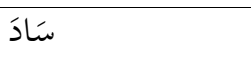 & 'to be Mr. - Mrs.' \\
\hline سِبْطُ & 'tribe' & --- & \\
\hline شَابُُُ شَابَّةُّ & ‘young man-woman’ & شَبَُّ & $\begin{array}{l}\text { 'to be young man- } \\
\text { woman' }\end{array}$ \\
\hline شَيْنْ - شَيْخَخُة & 'old man - woman' & شَاخَ & 'to get old' \\
\hline صِهْ & 'related by marriage' & صَاهَرَ & $\begin{array}{ll}\text { 'to be related by } \\
\text { marriage' }\end{array}$ \\
\hline صَاحِبُ - صَاحِبَة & 'friend' & صَحِبَ و صَاحَبَ & 'to be friend with' \\
\hline صَبِيُّ & 'child' & صَبِيُّ & 'to be childish' \\
\hline صَدِيْقِق - صَدِيْقَة & 'friend' & صَادَقَ & 'to be friend with \\
\hline عَدَدوُو & ‘enemy' & عَادَى & to hostile \\
\hline عَشَيْرِ - عَشِيْرَة & 'companion' & عَاشَرَ & $\begin{array}{l}\text { 'to be live with, to be } \\
\text { companied' }\end{array}$ \\
\hline فَتَى - فَتَاةُ & 'boy-girl' & فَفِيَّ & $\begin{array}{l}\text { 'to be young } \\
\text { man/woman' }\end{array}$ \\
\hline قَقَبيْلَة & 'tribe' & --- & \\
\hline
\end{tabular}


SASDAYA,

Gadjah Mada Journal of Humanities, Vol. 5. No. 1, 2021

\begin{tabular}{|c|c|c|c|}
\hline نَفِيْنبْ & 'leader' & نَقِبَ & 'to become a leader' \\
\hline وَلَلْد & 'child' & وَلَدَ & 'to beget, give birth' \\
\hline يَتِيْمِ - يَتِيمَةُة & 'orphan, fatherless' & يَتِمَ & 'to be an orphan' \\
\hline
\end{tabular}

Not all nouns within the table above has been realized as sifat. Only a few can be functioning as șifat, e.g. yatīmun 'orphan', sayyibatun 'widow', and 'aduwwun 'enemy':

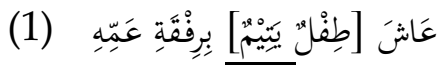

'[An orphan child] lived with his uncle'

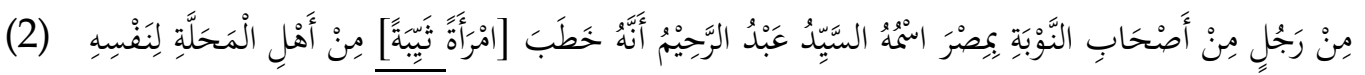

'One of the men from Nubia Egypt, his name is Mr. Abd Al-Rahim, proposed

to [a widowed woman] from Mahallah for himself'

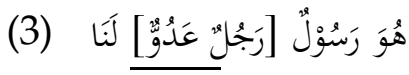

'He is a messenger, [a man, an enemy] to us'

Categorizing the nouns into SM may be caused by lexical related to, word-pattern, having feminine-form, and overlaping with tipe 1 which have lexical feature "age". The first is meaning related to. Analogically, any word that denotes the meaning of the term kinship and social category is classified as SM. Secondly, some of type 5 have similar

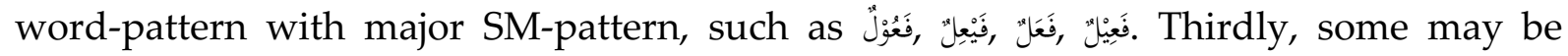
feminized with suffix $t \bar{a}{ }^{\prime} t a{ }^{\prime} n \bar{i}$ s marbūtah $\ddot{a}$. Fourthly, some classhood of type 5 also contain lexical content "age", such as waladun 'child', șabiyyun ' youth/child', fatā 'youth', syābbun 'youth', unsं̄ 'woman (an adult human female)'.

Type 6: Ism non-SM

The characteristics of type 6 are which a) must not be or may be functioning as șifat, b) has lexical features of absolute noun, c) is derived from denominal verbs and the verb

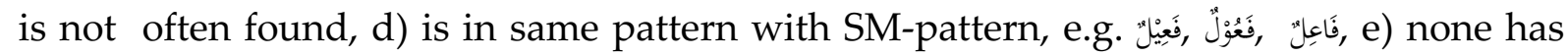
paradigmatic relation with ism tafḍil.

It is said that type 6 must not be functioning șifat because this type is restricted as șifat. Meanwhile, it said that it may be functioning as șifat because any ism may be functioning as șifat through metaphorical mechanism as type 4. So, this type is called with ism non-SM because that its syntactic behavior is so. The following provides examples of SM type 6 and available verbs as derivational axises.

\begin{tabular}{ll}
\hline $\mathrm{SM}$ & Verb \\
\hline
\end{tabular}

a) artefacts

\begin{tabular}{|c|c|c|}
\hline 'prison' & حَاصَرَ & 'to imprison' \\
\hline رَحِيْقِق & --- & - - \\
\hline س سَبْبِلْ 'way' ' 'way' & --- & -- \\
\hline صِرَاطُ 'path, way' & --- & -- \\
\hline أََرِيْكُ & --- & - - - \\
\hline
\end{tabular}




\section{SASDAYA,}

Gadjah Mada Journal of Humanities, Vol. 5. No. 1, 2021

$$
\begin{aligned}
& \text { حَدِيْدُ 'iron' } \\
& \text { احمتَدَ 'to become strong, like an iron' } \\
& \text { رَصَاصٌ 'lead, tin' } \\
& \text { رَصَّصن 'to be tinning' } \\
& \text { 'evening, afternoon' } \\
& \text { صَرِيْ } \\
& \text { عَشِيُّ 'evening' } \\
& \text { غَاسِقٌُ 'dark night, darkness' } \\
& \text { - - - - - } \\
& ---- \\
& ---\quad \ldots \\
& \text { أَغْسَتَّ '(of night) to be dark' }
\end{aligned}
$$

b) flora

ضَرِيْعِ 'a bitter thorny plant'

c) environtment

$$
\begin{aligned}
& \text { صَّبّبْ 'rainstorm' صَابَ 'to be raining down' } \\
& \text { مَارِج 'a smokeless flame' }
\end{aligned}
$$

d) body and other parts of human
صَدِيْدُ 'pus'
'to purulent'

e) onomatopoeia

حَسِيْنس (the) slightest sound

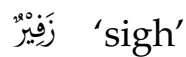

$$
\begin{aligned}
& \text { زَفَرَ 'to heave sigh' } \\
& \text { شَهْيْقُ 'sob' } \\
& \text { شَهِهََ 'to heave sob' }
\end{aligned}
$$

Some ism non-SM may be functioning as badal within tarkīb badaliy that it is similar construction with tarkīb wașfiy. Al-Gulāyainiy (1993: 238) defined tarkīb badaliy as tarkīb consisting of mubdal minhu 'subtituted-for' and badal 'substitute'. Meanwhile, Badawi et al. (2004: 123) counterparts tarkīb badaliy with appotition in English, for examples;

(1)

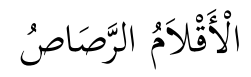

$$
\begin{array}{ll}
\text { al-aqlāmu } & \text { r-rașāṣu } \\
\text { pen plur. def. fem. nominative } & \text { lead sing. def. fem. nominative } \\
<\text { Mubdal minhu> } & <\text { badal }>
\end{array}
$$

pencils lit. 'lead pen'

(2)

$$
\begin{array}{ll}
\text { السِّكَةُ الحْدِيْدُ } & \\
\text { as-sikatu } & \text { l-hadīdu } \\
\text { road sing. def. fem. nominative } & \text { iron sing. def. masc. nominative } \\
<\text { Mubdal minhu> } & <\text { badal> }
\end{array}
$$

The railway lit. the iron road'

Both stuctures above are tarkīb badaliy consisting of badal, ar-rașașu 'lead' and al-hadìdu 'iron', and mubdal minhu, al-aqlāmu 'pen' and as-sikkatu 'road'. Badal and mubdal minhu must be agree in term definity and declension, but not in others. The grammatical meaning 


\section{SASDAYA,}

Gadjah Mada Journal of Humanities, Vol. 5. No. 1, 2021

of both tarkīb badaliy above is to characterize, viz. that material substance of mubdal minhu is come from badal.

Badawi et. al. (2004: 123) explained that characterizing material substance in classical Arabic can be expressed by either badaliy (apposition) or idäfiy (annexation). Both structures have been preserved within modern written Arabic. Another similar example found in the Qur'àn is as follows.

(3) مَّاءِ صَدِيدٍ

$\begin{array}{ll}M \bar{a} \text { in } & \text { șadìdin } \\ \text { water } & \text { pus } \\ <\text { Mubdal minhu> } & <\text { badal } \\ \text { 'pus water' } & \end{array}$

The classhood of type 6 include classhood of type 5 that they cannot be functioning as sifat. The basic difference between type 6 and type 5 is whether or not it can be feminized.

\section{CONCLUSION}

SM was often counterparted with adjectives by Western grammarians because the prominent lexical and grammatical features of SM is similar to adjectives. Nevertheless, $\mathrm{SM}$ is not similar exactly to adjective because SM has various lexical features other than adjectives and has grammatical features of noun as other Arabic nouns. In addition, the universality of adjectives in cross-linguistic studies of word classes is skeptical because not all languages have adjectives as an independent word class as well as Arabic.

$\mathrm{SM}$ is one of Arabic derivative noun subclasses that was given by traditional Arabic grammarians to accommodate other derivative nouns which can be functioning as sifat 'noun attribute' and have 'amal. But, it cannot be classified as ism fä'il, ism maf'ül, ism tafḍ̂̀ dan șigah mubālagah. In other words, SM is "a trash class" of other Arabic derivative nouns. It also shows that traditional Arabic grammar emphazised a morphosyntactic paradigm. This is understandable because the categorization of Arabic word classes must be on the basis of internal Arabic grammatical criteria. Therefore, as a result, SM has complexities of word-forms and lexical meanings.

The complexity of the SM notions can be fixed by the elaboration of modern linguistics especially about parts of speech and SM notions as internal grammatical critera. The elaboration suggests five principles of categorization, i.e. a) be functioning as sifat, b) lexical features c) the derivation of SM, d) SM-patterns, e) paradigmatic relation with tafdill. The application of five principles results in six types of SM, viz. 1) SM in a narrow sense, 2) $\mathrm{SM}$ as alternative word-pattern between ism fā'il and ism maf' $\bar{u} l$, 3) SM as absolute noun incorporation, 4) SM as lexicalization of metaphor, 5) SM as a term of kinship and social category, 6) ism non-SM. 


\section{SASDAYA,}

Gadjah Mada Journal of Humanities, Vol. 5. No. 1, 2021

\section{REFERENCES}

Abu-Chacra, F. (2007). Arabic: An essential grammar. Routledge.

Ad-Daḥdāḥ, A. (1996). Mu'jamu Qawā'idi l-lugati l-'Arabiyyati fi Jadwāli wa Lauhāa (6th ed.). Maktabah Lubnan.

Al-Gulāyainiy, M. (1993). Jāmi’ Ad-durūs al-'arabiyyah. Al-Maktabah Al-'așriyyah.

Al-Jārim, A., \& Amīn, M. (1999). Al-Balāgah Al-Wāḍiḥah: Al-Bayān, Al-Ma'āniy, Al-Badī’. Dār Al-Ma'ārif.

Al-Maṣārawah, Ṡāmir Ibrahim. (2007). Maqșūṣāt Șarfiyyah wa Naḥwiyyah. Jāmi'ah Mu 'tah.

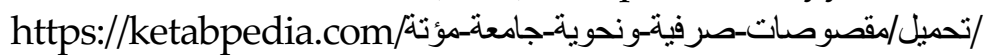

Al-’Ubaidiy, M. K. R., \& Al-Jamīliy, Z. F. 'Abd. (2012). Mubālagatu Ism Maf'ūl fi Al-'Arabiyyah. مجلة كلية الاداب, 1, 107-145.

Al-Yamaniy, J. M., \& An-Nūr, F. (2016). Aṣ-șifat al-musyabbahat fi al-qur’ān al-karīm. Majallat al-'ulūm wa l-buhūì al-islāmiyyah, 17 (1), 1-20.

As-Sāqiy, F. M. (1977). Aqsāmu Al-Kalāmi al-'Arabiy Min Ḥais̉u Asy-Syakl Wa Al-Waḍifah. Maktabah Al-Khanji. https:/ebook.univeyes.com/113972/pdf\%D8\%A3\%D9\%82\%D8\%B3\%D8\%A7\%D9\%85-

\%D8\%A7\%D9\%84\%D9\%83\%D9\%84\%D8\%A7\%D9\%85-

\%D8\%A7\%D9\%84\%D8\%B9\%D8\%B1\%D8\%A8\%D9\%8A-\%D9\%85\%D9\%86-

\%D8\%AD\%D9\%8A\%D8\%AB-\%D8\%A7\%D9\%84\%D8\%B4\%D9\%83\%D9\%84-

\%D9\%88\%D8\%A7\%D9\%84\%D9\%88\%D8\%B8\%D9\%8A\%D9\%81\%D8\%A9

'Azīz, M. (2009). Aș-șifatu l-musyabbahatu wa mubālagatu smi l-fā'ili fi l-Qur'āni l-karīmi: Dirāsatun șarfiyyatun-naḥwiyyatun-dilāliyyatun [Risālatun duktūrah, Jāmi'atu 'aini syamsin kuliyatu l-banāti li l-'ādābi wa l-'ulūmi wa t-tarbiyyati qismu l-lugati lالصفة-المشبهة-ومبالغة_اسم--arabiyyati wa ‘ādābihā]. https://ebook.univeyes.com/91979/pdf الفاعل-في-القرآ-الكريم

Badawi, E. S., Gully, A., \& Carter, M. (2004). Modern Written Arabic: A Comprehensive Grammar. Routledge.

Bauer, L. (2000). System vs. Norm: Coinage and institutionalization. In G. E. Booij, C. Lehmann, \& J. Mugdan (Eds.), Morphologie Ein internationales Handbuch zur Flexion und Wortbildung / Morphology An International Handbook on Inflection and WordFormation (Vol. 1, pp. 832-840). Walter de Gruyter.

Beck, D. (2002). The Typology of Parts of Speech Systems: The Markedness of Adjectives. Routledge.

Bybee, J. (2000). Lexical, morphological and syntactic symbolization. In G. Booij, C. Lehmann, \& J. Mugdan (Eds.), Morphologie Ein internationales Handbuch zur Flexion und Wortbildung / Morphology An International Handbook on Inflection and WordFormation (Vol. 1, pp. 370-377). Walter de Gruyter.

Dixon, R. M. W., \& Aikhenvald, A. Y. (2004). Adjective Classes in Typological Perspective. In R. M. W. Dixon \& A. Y. Aikhenvald (Eds.), Adjective classes: A cross-linguistic typology (pp. 1-49). Oxford University Press.

Dror, J. (2013). Adjectival Agreement in the Qur'ān Dror, Judith. 2013. "Adjectival Agreement in the Qur'ān." Bulletin d'études orientales,T. 62 (2013) (Institut Francais du ProcheOrient) 51-75. Bulletin d'études Orientales (Institut Francais Du Proche-Orient), 62, 5175.

Glanville, P. J. (2018). The Lexical Semantics of the Arabic Verb. Oxford University Press. 


\section{SASDAYA,}

Gadjah Mada Journal of Humanities, Vol. 5. No. 1, 2021

Goddard, C., \& Wierzbicka, A. (2014). Words and meanings: Lexical semantics across domains, languages, and cultures (First edition). Oxford University Press.

Ḥassān, T. (1985). Al-Lughat Al-'Arabiyyah Ma'nāha wa Mabnāha. Al-Hai' ah al-Miṣriyaah li alKitāb. https://ebook.univeyes.com/10099/pdf-2-اللغة_العربية_معناها-ومبناها

Haywood, J. A., \& Nahmad, H. M. (1962). A New Arabic Grammar of the Written Language. Percy Lund, Humphries \& Co. LTD.

Kridalaksana, H. (2008). Kamus Linguistik. Gramedia.

Lakoff, G., \& Johnson, M. (1980). Metaphors We Live. Chicago University Press.

Mithun, S., \& Barbara. (2000). Incorporation. In G. Booij, C. Lehmann, \& J. Mugdan (Eds.), Morphologie Ein internationales Handbuch zur Flexion und Wortbildung / Morphology An International Handbook on Inflection and Word-Formation (Vol. 1, pp. 916-928). Walter de Gruyter.

Mustarīhiy, Z. S. N. (2003). Aṣ-șifatu l-musyabbahatu fi 1-Qur’āni l-karīm: Dirāsatun Naḥwiyatun șarfiyatun dilāliyyatun [Ar-risālatu li Mutațallibāti darajati l-mājistīr, Qismu l-lugati l-'Arabiyyati Kuliyatu l-ādabi Jāmi'atu l-Yarmūk]. http://thesis.mandumah.com/Record/169133

Naḥlah, M. A. (1994). Al-Ism wa Aṣ-ṣifāt fi An-Naḥwi Al-'Arabiy wa Ad-Dirāsāti Alتحميل/الإسم-و الصفقتفي-/Rrūbiyyah. Dāru Al-Ma'rifah Al-Jāmi'iyyah. https://ketabpedia.com /النحو -العربي-و الدراسا

Wright, W. (1981). A Grammar of The Arabic Language (Vol. 1). Cambridge University Press.

\section{DATA SOURCES}

Anon. "International Corpus of Arabic." Available at: http://www.bibalex.org/ica/en/about.aspx [Accessed December 20, 2020a].

Anon. “Tanzil Project - Tanzil Documents." Available at: http://tanzil.net/docs/tanzil_project [Accessed December 20, 2020b].

Anon. "The Quranic Arabic Corpus - Word by Word Grammar, Syntax and Morphology of the Holy Quran." Available at: https://corpus.quran.com/ [Accessed December 20, 2020c].

Anon. "المعجم العربي الجامع." Available at: https://www.arabicterminology.com/ [Accessed December 20, 2020d].

Anon. "قاموس ومعجم المعاني منعدد اللغات والمجالات ـ قاموس عربي عربي و قاموس عربي انجليزي ثنائي." Available at: https://www.almaany.com/ [Accessed December 20, 2020e].

Munawwir, A.W. 1997. Kamus Arab-Indonesia Terlengkap. Surabaya: Pustaka Progresif. 